\title{
Kajian Budaya Konsumsi Cemilan Tradisional Kekerit setelah Melahirkan dalam Meningkatkan Kesehatan Ibu Nifas
}

\author{
Serilaila \\ Jurusan Kebidanan, Politeknik Kesehatan Banjarmasin, Indonesia \\ Email: serilaila11@yahoo.co.id
}

\begin{abstract}
Cultural Study of Consumption of Traditional Kekerit Snacks after Childbirth in Improving Postpartum Maternal Health. Kekerit which contains grains, rhizomes, and medicinal plants commonly consumed by the puerperal mother in Imigrasi Permu Village of Kepahiang Regency, it was believed to be useful to restore health. The study was to find out the culture of consuming kekerit snack on postpartum mothers to restore health. A qualitative study of ethnographic approaches was performed on mothers who had given birth at Imigrasi Permu Village in April-October 2017 to 7 core informants and 5 additional informants with a purposive sample and snowball techniques through an in-depth interview to data saturation. Data analysis was using an editing analysis model. The result showed that kekerit was a snack consisting of 3040 ingredients and become a cultural snack for postpartum mother that useful for warm the body, reduce bloating and appetite. Development of kekerit snack is needed with further research, socialization, and cooperation to improve the product quality so it is feasible to be good healthy food and using local wisdom.
\end{abstract}

Keywords: Health Recovery, Kekerit, Post Partum

\begin{abstract}
Abstrak: Kajian Budaya Konsumsi Cemilan Tradisional Kekerit setelah Melahirkan dalam Meningkatkan Kesehatan Ibu Nifas. Kekerit yang berisi biji-bijian, temu-temuan dan tanaman obat biasa dikonsumsi ibu nifas di Desa Imigrasi Permu Kabupaten Kepahiang yang dipercayai berguna untuk memulihkan kesehatan. Tujuan penelitian untuk mengetahui budaya mengkonsumsi cemilan kekerit pada ibu nifas untuk memulihkan kesehatan. Penelitian secara kualitatif pendekatan etnografi pada ibu yang telah melahirkan di Desa Imigrasi Permu pada bulan AprilOktober 2017 kepada informan inti 7 orang dan 5 informan tambahan dengan teknik purposive sample dan snow ball melalui indept interview hingga saturasi data. Analisis data menggunakan model analisis editing. Hasil: Kekerit merupakan cemilan yang terdiri dari 30-40 bahan dan telah menjadi budaya bagi ibu nifas yang dirasakan berhasiat berupa: badan menjadi hangat, kurangi kembung dan nafsu makan. Perlu pengembangan terhadap cemilan kekerit dengan penelitian lebih lanjut dan sosialisasi serta kerjasama untuk meningkatkan mutu produk sehingga layak untuk dijadikan makanan sehat sebagai kearifan lokal yang bermanfaat.
\end{abstract}

Kata Kunci: Kekerit, Pemulihan Kesehatan, Ibu Nifas

Masa nifas merupakan masa pemulihan terutama organ reproduksi dari hamil ke kondisi awal yang terjadi setelah persalinan hingga 6 minggu setelah persalinan. Pada masa ini ibu mengeluh setidaknya 1 masalah, berupa: nyeri abdomen, nyeri punggung, nyeri kepala, masalah puting susu dan masalah lainnya (Saifuddin, et al, 2009). Mengatasi masalah kesehatan pada masa nifas sebagian masyarakat mempercayai untuk melakukan pantangan (Abdullah, et al, 2016) ritual-ritual atau meminum ramuan sehingga dapat meningkatkan kesehatan dan menguatkan tubuh ibu (Handayani, 2010 )

Budaya meminum ramu-ramuan seperti jamu khususnya masyarakat Jawa diyakini sebagai pengobatan tradisional yang aman dan murah. Keadaan ini dilakukan oleh ibu-ibu hamil, bersalin, nifas dan menyusui di Desa Kejora Kelaten Selatan. Hasil penelitian didapatkan $80,5 \%$ ibu nifas mengonsumsi jamujamuan setiap hari sebagai upaya menjaga kesehatan (Paryono \& Kurniarum, 2014). Data Riset Kesehatan Dasar (Riskesdas) 2013 didapatkan 49,0\% rumah tangga memanfaatkan ramuan dalam pengobatan alternatif (Kementerian Kesehatan RI, 2013). Hal ini juga terjadi pada ibu nifas terutama ibu yang bersuku Sunda di Desa Imigrasi Permu Kecamatan Kepahiang Propinsi Bengkulu berupa kebiasaan mengkonsumsi cemilan kekerit yang berisikan ramuan sebagai makanan pemulih kesehatan setelah melahirkan. 
Kekerit merupakan sebutan terhadap makanan cemilan bagi ibu nifas yang berbentuk bubuk yang bahannya terdiri dari biji-bijian, temu-temuan, bumbu masak, dan daun-daunan, akar atau batang atau tanaman obat. Cemilan ini biasa dikonsumsi ibu setelah melahirkan yang dirasakan cukup bermanfaat bagi kesehatan dan telah dipersiapkan sejak ibu hamil. Cemilan kekerit ini ada kesamaan dengan jamu galohgor yang ada di Desa Sukajadi Kecamatan Taman Sari Bogor dari bentuk dan waktu konsumsi setelah melahirkan, namun berbeda komposisi bahan yang lebih banyak yaitu 65 macam (Leatemia, 2010).

Konsumsi ramu-ramuan atau jamu dipengaruhi oleh budaya, budaya yang berkembang dan berubah mempengaruhi perilaku konsumsi konsumen jamu. Perubahan tersebut berakibat terjadinya perubahan pada faktor psikologis konsumen misalnya persepsi, sikap terhadap jamu, motivasi minum jamu, pengetahuan dan kepercayaan tentang jamu dan gaya hidup yang terkait dengan hidup sehat dari bahan alami (Andriati \& Wahyudi, 2016).

Cemilan kekerit ini telah berkembang di masyarakat yang dirasakan memiliki khasiat bagi pemulihan kesehatan bagi ibu nifas, namun belum ada kajian tentang tata cara mengkonsumsi dan perkembangan budaya sehingga makanan ini dapat dikembangkan sebagai kearifan lokal di Desa Imigrasi Permu Kabupaten Kepahiang Propinsi Bengkulu. Tujuan penelitian untuk mengetahui budaya mengonsumsi cemilan kekerit oleh ibu nifas dalam meningkatkan kesehatan di Desa Imigrasi Permu Kabupaten Kepahiang Propinsi Bengkulu.

\section{METODE}

Penelitian ini telah dilakukan dengan metode kualitatif dan pendekatan etnografi yang bertujuan untuk menggali secara mendalam tentang budaya mengkonsumsi kekerit dan perkembangannya di Desa Imigrasi Permu Kabupaten Kepahiang. Pendekatan digunakan diharapkan dapat mengungkapkan perkembangan budaya dan pengalaman yang dirasakan oleh ibu selama mengkonsumsi hingga persepsi manfaat yang dirasakan. Penelitian dilaksanakan di Desa Imigrasi Permu Kabupaten Kepahiang Propinsi Bengkulu dari bulan Juni sampai September 2017.

Subjek penelitian adalah ibu-ibu yang telah melahirkan pada tahun 2017 yang berjumlah 7 orang. Penentuan informan tersebut dipilih dengan mengunakan teknik purposive sampling dan snow ball dengan kriteria sedang konsumsi kekerit setelah melahirkan dan dibedakan waktu setelah melahirkan dari hari pertama sampai 2 bulan, suku, paritas dan jenis persalinan. Data dikumpulkan melalui in-depth interview yang langsung kepada informan, setelah dilakukan wawancara hasilnya tidak ada informasi yang baru atau sudah jenuh/saturasi, maka subyek penelitian dihentikan. Selain itu dilakukan triangulasi terhadap data dan sumber dengan melakukan wawancara dan observasi. Informan tambahan yaitu: bidan 1 orang, tokoh adat 1 orang, pembuat kekerit 1 orang dan 2 orang dari orang tua informan. Informasi lain yaitu dengan cara observasi langsung terhadap tata cara pembuatan dan konsumsi kekerit serta budaya yang ada dan berkembang dilokasi penelitian. Selanjutnya data dinalisis yang dilakukan pada setiap tahap hasil wawancara yang telah ditranskripkan hingga akhir penelitian dengan menggunakan model analisis editing (Saryono \& Anggraeni, 2013).

\section{HASIL}

\section{Gambaran Daerah Penelitian}

Penelitian ini telah dilakukan pada wilayah Desa Imigrasi Permu Kecamatan Kepahiang, Kabupaten Kepahiang, Propinsi Bengkulu. Desa ini berbatasan, sebelah Utara dengan Desa Permu, sebelah Selatan dengan Desa Taba Saling, sebelah Barat berbatasan dengan Kelurahan Pasar Ujung dan sebelah Timur berbatasan dengan desa Suka Merindu. Desa Imigrasi Permu memiliki 4 dusun yaitu: Dusun Tonggoh, Lembak, Kaum dan Talang. Desa ini dinamakan Desa Imigrasi karena sebagian besar (65\%) penduduknya beretnis sunda sebagai transmigrasi sejak tahun 1930-an. Banyaknya suku sunda ini maka dalam kehidupan sehari-hari dari kebiasaan makanan, bahasa dan budaya seperti pada saat acara harihari besar lebih banyak menggambarkan tradisi dari Suku Sunda Jawa Barat dengan menampilkan wayang golek, pencak silat dengan tetabuhan khas sunda.

\section{Karakteristik Informan}

Informan inti dalam penelitian ini sebanyak 7 orang dan telah memiliki anak 1-3 orang, dengan seluruhnya usia 20-35 tahun, dan sebagian besar pendidikan SLTA, sosial ekonomi menengah, jenis persalinan sebagian besar normal dengan bidan dan 1 orang bedah sesar 
serta 4 informan suku sunda dan lainnya dari masing-masing 1 yaitu: Jawa, Rejang dan Serawai.

\section{Budaya Konsumsi Kekerit}

Cemilan kekerit merupakan hasil budaya yang didapat secara turun temurun dan dipertahankan hingga sekarang. Hasil penelitian didapatkan seluruh informan mengetahui cemilan kekerit dari orang tua dan nenek moyang mereka dari Suku Sunda dan mengikuti sebagai tradisi yang telah terbiasa dilakukan. Ungkapan itu disampaikan oleh informan:

Kekerit...ya....tiletik tos dibejaan iye ngaranna kekerit...ti nini ninik tos mam nak... itu...tradisi kalu udah ngelahirken aya ie,kekerit, kalau istilahna dari mana..enggak tau..dari mak itu dari mak mak...ninik (artinya: kekerit ya..dari kecil sudah dikatakan ini namanya kekerit..dari nenek moyang sudah makannya...itu sudah tradisi kalau sudah melahirkan ada itu kekerit, kalau istilahnya dari mana enggak tahu..dari ibu itu dari ibu ibu..nenek) (Inf $M$ )

Hal ini didukung oleh informan tambahan Ibu $\mathrm{S}$ umur 65 tahun yang biasa konsumsi dan membuat pesanan pembuatan kekerit ini, pernyataanya:

Kalau kekerit ni dari kito nila, suku sunda, kito ni aslinyo dari Bogor, Ciapus kato orang tuo kito... dari nini ninik la biaso buat, awalnyo dulu mak kan buat, kito anak-anak nurut.. sudah melahirkan pasti buat, kalau idak buat rasonyo dak enak, entah ado raso yang kurang, tambah lagi dulu obat-obat idak ado, jadi makanan inilah yang jadi badan kito sehat (Ibu S).

Pembuatan dan konsumsi kekerit telah menjadi tradisi sehingga informan merasa tidak nyaman kalau tidak sampai menyediakan makanan ini yang selalu disuguhkan pada saat kunjungan nifas. Cemilan kekerit telah berkembang dan bukan hanya dikonsumsi oleh ibu-ibu suku Sunda namun telah jadi cemilan juga bagi ibu nifas dari Suku Jawa dan suku asli Bengkulu seperti Serawai dan Rejang. Pernyataan ibu dari Suku Jawa, pernyataan:

Kalau saya suka kekerit karena saya kan orang jawa, biasa makan jamu-jamuan pas kalau lihat orang melahirkan makan dan biasa disuguhkan dan saya suka, dibanding јати ini enak...ini saya suka makannya, badan enak dan kenyang(Inf A).

Pernyataan dari ibu Suku Serawai, sebagai berikut:
Kalau kekerit ni....dari kecilkan sering dibawa samo mama lihat bayi terus biasanyo makan... terus dulu mama melahirkan aku jugo makan ini, dan kato mama nenek yang buat...nenek minta tolong orang kito sunda, itu bibik $S$, terus aku melahirkan yo dibuat jugo.. enak rasonyo badan ni....(Inf He)

Konsumsi kekerit sudah menjadi tradisi pada saat setelah melahirkan untuk disediakan dan telah diturunkan kepada generasi berikutnya serta disebarkan secara tidak langsung kepada warga diluar Suku Sunda disekitar wilayah di Desa Imigrasi Permu.

\section{Pembuatan dan Pengolahan Kekerit}

Kekerit ini sebagian besar informan dibuatkan langsung oleh orang tua atau keluarga dan disiapkan paling lambat 1 bulan sebelum melahirkan untuk mengumpulkan bahan hingga diolah dijadikan cemilan. Bahan-bahannya didapatkan dengan cara dibeli dipasar atau disekitar desa di halaman rumah dan mencari di sawah-sawah, di kebun atau ke hutan terutama untuk bahan daun-daunan, Pernyataan informan:

Buat kekerit ini kalau kami, ibu mulai kumpulkan bahannya itu umur hamil saya 7 bulan la mulai, karena bahan-bahannya harus dijemur, kalau panas bisa 2-3 hari kering, sedikit-sedikit seperti jahe, kunyit, kencur, koneng gede, lempuyang itu kebetulan ada tanamannya, enggak beli...itu dibersihkan dulu terus diiris dan jemur...nah kalau itu masih gampang carinya tapi kalau seperti daun-daun seperti babandotan, beluntas, jawer kotok, kibeling, cari disawah atau pinggir-pingir rumah ni, tapi seperti apa itu...kapituher itu susah carinya...dikebun jauh tempatnya $(\operatorname{Inf} Y)$

Bahan pembuatan kekerit dari masingmasing informan berbeda-beda terutama takaran yang disesuiakan dengan keinginan ibu nifas. Ungkapan orang tua yang membuat kekerit:

Kalau takarannya yang terbanyak beras ketan, kacang-kacangan, terus jahe tapi kalau daun-daun itu begantung yang suka, kalau mau pahit, rasa seperti jamu banyakkan yang daun-daunnya....tapi kalau sekarang pada enggak suka yang pahit, jadi dikurangi dan perbanyak ketan, terus kacang-kacangan...gurih tu rasanya (Orang Tua $Y$ )

Hasil wawancara dan observasi kepada orang tua dan Ibu $\mathrm{S}$ yang biasa menerima pesanan pembuat kekerit didapatkan perbedaan takaran dan cara pembuatan kekerit, namun 
kandungan bahannya sama adanya biji-bijian, umbi-umbian, bumbu masak, tumbuhan obat dengan patokan dasarnya pada beras ketan yang berjumlah lebih kurang 30-40 macam. Rangkuman hasil tersebut dijelaskan pada Tabel 1. dibawah ini:

Tabel 1. Nama-nama Bahan dan Kisaran Takaran Pembuatan Kekerit

\begin{tabular}{ll}
\hline $\begin{array}{c}\text { Nama Tradisional } \\
\text { Biji-bijian }\end{array}$ & \multicolumn{1}{c}{$\begin{array}{c}\text { Kisaran Takaran } \\
\text { keluarga }\end{array}$} \\
\hline $\begin{array}{l}\text { Ketan hitam/ } \\
\text { putih }\end{array}$ & Ketan cupak/ 1600 gr \\
\hline Jagung & 1 genggam-1/4 $\mathrm{kg}$ \\
\hline Kacang hijau & $1 / 4 \mathrm{~kg}$ \\
\hline Kacang kedelai & $1 / 4 \mathrm{~kg}$ \\
\hline Kacang tanah & $1 / 4 \mathrm{~kg}-1 \mathrm{~kg}$ \\
\hline Kacang Jaat & $0-$ segengggam \\
\hline Umbi-umbian/ Temu-temuan \\
\hline Jahe & $1 / 4 \mathrm{~kg}$ \\
\hline Kencur & $1 / 4 \mathrm{~kg}$ \\
\hline Kunyit & $1 / 4 \mathrm{~kg}$ \\
\hline Koneng gede & $1-3$ ruas \\
\hline Lempuyang & $1-3$ ruas \\
\hline Panglai Hideng & $0-3$ ruas \\
\hline Bumbu masak & \\
\hline Kapulaga & $0-1$ sdm \\
\hline Ketumbar & $0-1$ sdt \\
\hline Lada & $0-1$ sdt \\
\hline Pala & $0-1$ sdt \\
\hline Cabe jawa & $0-3$ buah \\
\hline Tumbuhan Obat (daun, akar, batang) \\
\hline Babadotan & Secukupnya \\
\hline Beluntas & Secukupnya \\
\hline Jawer kotok & Secukupnya \\
\hline Kiurat & Secukupnya \\
\hline Kibeling & Secukupnya \\
\hline Kiremeh daging & Secukupnya \\
\hline Kimulas & Secukupnya \\
\hline Kumis kucing & Secukupnya \\
\hline Mangkokan & Secukupnya \\
\hline Memeniran & Secukupnya \\
\hline Sembung & Secukupnya \\
\hline Kapituher & Secukupnya \\
\hline Antanan besar & Secukupnya \\
\hline Antanan berit & Secukupnya \\
\hline Tapak liman & Secukupnya \\
\hline Handelem & $0-$ secukupnya \\
\hline Daun saga & $0-$ secukupnya \\
\hline Daun pepaya & $0-3$ pelepah \\
\hline & \\
\hline
\end{tabular}

Tabel 1. Bahan dan takaran masingmasing informan ada perbedaan, dari yang tidak menggunakan atau secukupnya terutama pada tanaman obat dari hanya beberapa lembar sampai seikat sebesar ibu jari. Cara pembuatan kekerit yaitu: Semua bahan pada Tabel 1. dilakukan penjemuran sampai kering, selanjutnya dimasak dengan cara digongseng dengan api kecil.
Memasaknya dipisahkan sesuai dengan kategori bahan, setelah masak dilakukan penumbukan dengan menggunakan alat tradional alu namanya. Penumbukan bahan dilakukan secara terpisah antara tanaman obat, umbi-umbian, bumbu masak yang ditumbuk hingga dibuat halus, untuk mendapatkan hasil yang baik ada yang menggunakan saringan gandum, namun untuk biji-bijian ditumbuk dalam keadaan kasar dengan gunakan saringan kasar sehingga masih dapat dikunyah. Setelah semua selesai ditumbuk selanjutnya semua bahan disatukan dan diaduk hingga rata dan terakhir kekerit disimpan dalam toples yang kering dan bersih.

\section{Cara Penyajian dan Konsumsi Kekerit}

Cemilan kekerit yang berbentuk bubuk disajikan kepada ibu nifas segera setelah melahirkan dan hampir seluruhnya konsumsi 3-4 kali sehari sekitar $\pm 2-3$ sendok makan perkali makan. Pernyataan informan:

Dihakan tos ngalahirken...dua tilu sendok sakali daang nu diwadahken kapiring letik...isuk daang, berang engkek sore deik...lewih kurang tilu kali...dihakang isukisuk atos mandi, sa encan daang...tras besi aya tamu nu nempok orok urang ngadaang ogek (artinya: dimakan setelah melahirkan..dua tiga sendok sekali makan yang diletakkan dipiring kecil...pagi makan, siang dan sore lagi..lebih kurang tiga kali..pagi, siang dan sore..dimakan pagi-pagi setelah mandi, sebelum makan...trus bila ada tamu yang lihat bayi...kita makan juga (Inf M).

Konsumsi kekerit ada sebagian kecil informan dilakukan setelah buang air besar lancar dan menunggu setelah 3 hari. Mengkonsumsi kekerit ini dilakukan setiap hari sampai habis, rata-rata yang dibuatkan sampai 2 toples ukuran 2 liter dan habis hingga 2 bulan atau lebih. Untuk mendapatkan rasa yang sesuai ibu-ibu telah melakukan berbagai cara antara lain dengan cara mencampurkan dengan gula, penyedap rasa atau di buat halus, namun hal ini tidak sesuai dan rasanya tidak disukai. Pembuatan kekerit dirasanya enak bila jumlah kacang tanah dibanyakkan serta tanaman obatnya sedikit dikurangi.

\section{Khasiat Konsumsi Kekerit}

Konsumsi kekerit dirasakan bermanfaat bagi ibu nifas diungkapkan oleh seluruh informan seperti badan terasa hangat dan badan terasa enak 
serta sebagian merasa bau anak lebih segar, diungkapkan sebagai berikut:

Badan terasa panas, hangat gitu....nafsu makan nambah, jadi enak lah ka badan, terus mungkin darah jugo cepat kering...anak juga enak baunya, kalau air susu lancar aja (Inf A).

Selain itu khasiat yang dirasakan untuk mengatasi kembung dan merangsang nafsu makan, pernyataannya:

Untuk perut kembung bisa, saya pernah waktu itu kembung, nah..makan langsung enak, untuk nafsu makan...ini juga sama ibu ada yang pesan untuk orang tua yang malas makan...ini bagus dan lebih sehat katanya (Inf Y)

Khasiat yang dirasakan didukung oleh bidan yang biasa merawat ibu-ibu nifas di Desa Imigrasi Permu, ungkapannya:

Kalo aku lihat yo bu...ibunyo lebih segar, dari hari pertamo tu la enak.... sekilas aku tengok hawanyo lebih enak idak bau, terus caknyo lebih sehat... perdarahannyo jugo cak itu... ibu $Y$ belakangko bu la cepat kering.....tali pusat jugo cak nyo bu....cepat lepas, kemarin tu limo hari (Inf. Bidan A).

Khasiat yang dirasakan oleh ibu berupa badan menjadi hangat, menghilangkan perut kembung, dan meningkatkan napsu makan meningkatkan kesehatan ibu terutama dalam pemulihan kesehatan. Khasiat yang dirasakan menjadikan cemilan ini selalu dibuat dan disiapkan oleh keluarga untuk ibu nifas baik dengan membuat sendiri atau memesan kepada beberapa ibu-ibu Suku Sunda yang biasa membuatnya.

\section{PEMBAHASAN}

Cemilan kekerit telah menjadi makanan tradisional yang diturunkan dari generasi ke generasi oleh masyarakat di Desa Imigrasi Permu Kabupaten Kepahiang Bengkulu melalui pembiasaan sehingga menjadi budaya. Menurut hasil penelitian Andriati \& Wahyudi (2016) mengkonsumsi jamu merupakan suatu budaya. Budaya yang berkembang karena persepsi dan kebutuhan, utamanya kalau individu tersebut sakit. Sebagai sebuah budaya jamu dikenalkan selain dari iklan juga dikenalkan dan disosialisasikan dan disarankan dari keluarga dan orang-orang terdekat sehingga menjadi pola kebiasaan dan dilestarikan.

Kebiasaan mengkonsumsi kekerit dirasakan bermanfaat dan aman sehingga dari anak-anak telah disosialisasikan saat menjenguk bayi, hal ini menjadi pesan. Pesan ini membentuk komunikasi kesehatan secara natural melalui tanaman herbal yang dapat menyembuhkan penyakit. Pembentukan pesan dari generasi ke generasi, menciptakan pemaknaan tersendiri sehingga jamu diyakini sebagai bahan obat, begitupun terhadap konsumsi kekerit (Kartika, 2017).

Bahan-bahan kekerit terutama temutemuan dan tanaman obat seperti layaknya jamu, karena jamu memiliki bahan seperti: jahe, lengkuas, kunyit,temu lawak, temu ireng, asam, sambiloto, brotowali dan lain-lain. (Kartika, 2017). Namun bahan kekerit berbeda dengan jamu yang mengandung biji-bijian yang berisi beras ketan dan kacang-kacangan sehingga saat dikonsumsi dapat langsung dimakan karena rasanya enak dan menjadi cemilan. Hal ini membedakan dengan jamu yang biasanya berbentuk bubuk yang perlu diseduh dengan air atau sudah berbentuk cair seperti jamu gendong atau godog (Wulandari \& Azrianingsih, 2014).

Bahan dasar pembuatan kekerit masingmasing informan terdiri dari kelompok bijibijian, temu-temuan, bumbu masak dan tanaman obat. Namun jumlah dan komposisi berbeda-beda dan bergantung pada ketersediaan bahan baku, selera dan kemampuan membeli serta mencari terutama tanaman obat. Tanaman obat berupa seperti pegagang, kapituher, handeleum dan lainlain penyediaannya dengan cara mencari disekitar lingkungan di dekat rumah, disawah, dikebun atau ke hutan. Tanaman ini belum dibudidayakan menjadi tanaman obat keluarga, sedangkan tanaman ini bermanfaat yang dapat digunakan sebagai upaya preventif dalam pengobatan. Menurut WHO sekitar 25\% obat modern atau obat konvensional berasal dari tumbuhan, sehingga dengan membudidayakan selain mempermudah mendapatkannya juga dapat dijadikan sumber masukan pendapatan bagi keluarga (Aditama, 2015).

Rasa kekerit saat ini sedikit berbeda dengan aslinya terutama bagi informan yang tidak suka rasa pahit sehingga dikurangi jenis tanaman obat dan memperbanyak biji-bijian terutama kacang tanah. Untuk mendapatkan rasa yang sesuai keinginan konsumen perlu dilakukan uji organoleptik terhadap kekerit dengan menggunakan indera manusia untuk mengukur tekstur, penampakan, aroma dan flavor produk pangan. Uji ini bermanfaat dalam pengembangan produk dengan meminimalkan resiko dalam pengambilan keputusan. Evaluasi sensori dapat digunakan untuk menilai adanya perubahan yang dikehendaki atau tidak dikehendaki dalam produk, sehingga dapat diketahui penerimaan dan 
kesukaan atau preferensi konsumen (Koswara, 2006). Adanya uji tersebut didapatkan kekerit yang sesuai selera konsumen dengan tidak mengurangi khasiat yang terkandung.

Kekerit yang berbentuk serbuk yang mengandung biji-bijian seperti beras ketan, kacang tanah, dan kacang kedele merupakan sumber energi yang baik dijadikan cemilan atau sebagai makanan selingan yang dibutuhkan ibu nifas. Kebutuhan setiap ibu nifas setiap hari sampai usia 6 bulan pertama memerlukan tambahan berupa energi 330 kalori, protein $20 \mathrm{~g}$, $11 \mathrm{~g}$ lemak, $45 \mathrm{~g}$ karbohidrat (Kementerian Kesehatan RI, 2014). Rata-rata informan setiap harinya mengkonsumsi kekerit 2-3 kali atau lebih kurang 50-100 gram, hasil uji kandungan terhadap kekerit dari 100 gram mengandung 443 kalori, $5,6 \%$ gr karbohidrat, $18,7 \%$ gr protein, $38,4 \%$ gr lemak (Serilaila \& Wahyuni, 2016). Kekerit ini sangat bermanfaat pada ibu nifas yang memerlukan sumber energi tambahan dan menjadi alaternatif terutama pada masyarakat yang mempunyai kebiasaan berpantang sehingga dapat menurunkan kesehatan.

Khasiat yang dirasakan setelah konsumsi kekerit berupa badan hangat, lebih segar, dan meningkatkan nafsu makan sehingga memulihkan kesehatan. Menurut RISKESDAS 2013 didapatkan 52,7\% rumah tangga di Indonesia memanfaatkan ramuan yang berguna untuk pemulihan kesehatan dan kebugaran (Kementerian kesehatan RI, 2013). Khasiat yang dirasakan dilihat dari Tabel 1. kekerit mengandung kencur yang dapat digunakan sebagai obat batuk, menghangatkan badan, juga menghilangkan gas dari perut. Selain itu adanya rimpang jahe yang berkhasiat untuk peluruh kentut, mengeluarkan angin, dan juga sebagai stomakik, yakni menambah nafsu makan dan menguatkan lambung (Hidayat \& Napitupulu, 2015). Khasiat kekerit ini telah dilakukan uji dengan menggunakan tikus putih yang telah melahirkan didapatkan: ada pengaruh konsumsi kekerit terhadap kebugaran melalui uji renang. Hasil didapatkan rata-rata waktu renang tikus yang diberi kekerit dapat mencapai waktu selama

\section{DAFTAR PUSTAKA}

Abdullah, S. Z. S., Nilan, P., \& Germov, J. 2016. Postpartum Dietary Restrictions and Taboos among Indigenous Temiar Women in Peninsular Malaysia: A Qualitative Study. Malaysian Journal of Nutrition, 22(2).

Aditama, Tjandra Yoga. 2015. Jamu dan
101 detik dibandingkan tikus kontrol yang hanya 69 detik pada hari pertama setelah melahirkan dengan nilai $p=0,039$ (Serilaila \& Wahyuni, 2016).

Napsu makan meningkat dan badan menjadi bugar sangat diperlukan bagi ibu nifas dan dapat mempercepat proses pemulihan kesehatan. Ibu yang sehat mendorong dapat melakukan aktifitas, aktifitas yang dilakukan berguna baik secara fisik, mental dan sosial. Secara fisik dapat mengurangi rasa sakit dan kelelahan dan secara psikologis akan menekan kecemasan dan meningkatkan kenyamanan serta secara sosial akan timbul kemandirian yang dapat berguna memenuhi kebutuhan diri dan bayinya (Kalisch et al, 2013).

\section{SIMPULAN}

Kekerit merupakan cemilan yang dikonsumsi ibu nifas yang berisi biji-bijian dan tanaman obat layaknya jamu dan menjadikan tradisi turun temurun karena dirasakan khasiatnya berupa badan menjadi hangat, nyaman, dan meningkatkan nafsu makan yang diperlukan bagi ibu nifas untuk meningkatkan dan memulih kesehatan sehingga dapat melakukan aktifitas yang berguna bagi kesehatan fisik, mental dan sosial.

\section{SARAN}

Cemilan kekerit ini perlu pengembangan lebih lanjut untuk dilakukan uji fungsional dan uji organoletip sehingga cemilan ini layak menjadi alternatif makanan tambahan bagi ibu nifas yang sehat dan sesuai selera konsumen. Perlunya budidaya terhadap tanaman obat yang terkandung dalam kekerit melalui pengembangan tanaman obat keluarga sehingga mudah mendapatkannya dan dapat menjadi aset bagi daerah khususnya Desa Imigrasi Permu sebagai kearifan lokal dan dapat menjadi sumber pendapatan keluarga.

Kesehatan (II). Jakarta: Badan Penelitian dan Pengembangan RI.

Andriati, \& Wahyudi, R. T. 2016. Tingkat penerimaan penggunaan jamu sebagai alternatif penggunaan obat modern pada masyarakat ekonomi rendah-menengah dan atas Society's acceptance level of herb 
as alternative to modern medicine for lower, middle, and upper class group. Masyarakat, Kebudayaan Dan Politik, 29(3), 133-145.

Koswara. S. 2006. 2006. Pengujian Organoleptik (Evaluasi Sensori) dalam Industri Pangan, 1-37. ebookpangan.com

Handayani, S. 2010. Aspek Sosial Budaya Pada Kehamilan, Persalinan dan Nifas di Indonesia. Infokes, 1(2), 21-27.

Hidayat, S., \& Rodame M Napitupulu. (n.d.). 2015. Kitab Tumbuhan Obat. Jakarta: Agriflo.

Kalisch, B. J., Lee, S., \& Dabney, B. W. 2013. Outcomes of inpatient mobilization: A literature review. Journal of Clinical Nursing, 23(11), 1486-1501. http://doi.org/http://doi.org/10.1111/jocn.1 2315

Kartika, Tina. 2017. Tradisi Minum Jamu: Konsep Komunikasi Kesehatan dari Generasi ke Generasi. Prosiding Seminar Nasional Komunikasi Publik Dan Dinamika Masyarakat Lokal, 56-64. jurnal.fisip.unila.ac.id/index.php/prosiding mikom/article/download/312/278

Kementerian Kesehatan RI. 2013. RISKESDAS2013 dalam Angka dan Buku (pp. 70-76). Jakarta.
Kementerian Kesehatan RI. 2014. Pedoman Gizi Seimbang. Jakarta.

Leatemia, R. R. 2010. Aktivitas Antioksidan Jamu Galohgor pada Tikus Putih (Rattus sp). [Tesis]. Institut Pertanian Bogor.

Paryono, \& Kurniarum, A. 2014. Kebiasaan Konsumsi Jamu Untuk Menjaga Kesehatan Tubuh Pada Saat Hamil dan Setelah Melahirkan Di Desa Kajora Klaten Selatan. Jurnal Terpadu Ilmu Kesehatan, $3(1), 64-72$.

Saifuddin, Ab; Adriaansz, G., Wiknjosastro, H., Waspodo, D. 2009. Buku Acuan Nasional Pelayanan Kesehatan Maternal dan Neonatal. Jakarta: Yayasan Bina Pustaka Sarwono Prawirohardjo.

Saryono, \& Mekar Dwi Anggraeni. 2013. Metode Penelitian Kualitatif dan Kuantitatif dalam Bidang Kesehatan. Jakarta: Nuha Medika.

Serilaila, \& Ely Wahyuni. 2016. Pengaruh Konsumsis Kekerit oleh Tikus Putih Terhadap Involusi Uteri dan Kebugaran (Laporan Pe). Bengkulu: Poltekkes Kemenkes Bengkulu.

Wulandari, R. A., \& Azrianingsih, R. 2014. Etnobotani Jamu Gendong Berdasarkan Persepsi Produsen Jamu Gendong di Desa. Jurnal Biotropika, 2(4), 198-202. 